\title{
Services Marketing Theory Revisited: An Empirical Investigation into Financial Services Marketing
}

\author{
Anisa Jan
}

\begin{abstract}
Recently many authors (Enis and Roering 1981; Wright 1995; Lovelock and Gummeson 2004; Vargo and Lusch 2004) have challenged the uniqueness of service particularly with advancements in technology. However some authors are still having a strong belief that services are different than tangible goods and therefore require different marketing frameworks. This has resulted in a fresh 'services-marketing-is-different' debate. The present article tests the validity of basic assertion of services marketing theory that four specific characteristics - intangibility, heterogeneity, inseparability, and perishability-make services uniquely different from goods and also analyses the data for difference in perception across public and private sector financial firms. The data has been collected through structured questionnaire administered among 877 managers of financial service firms which is regarded as one of the pure service. Findings suggest the theory is pretty much valid till now, however the significance of each characteristic varies across services. The study concludes that the biggest challenge faced by services firms is heterogeneity and not intangibility as reported by most of the earlier studies. Marketing managers of service firms can use the study to identify the challenges that are unique to their services and therefore focus on the most critical issues facing them.
\end{abstract}

\section{Introduction}

Most of the challenges in service marketing arise from the basic characteristics of services like intangibility, heterogeneity, inseparability and perishability and are consistently cited as IHIP. These characteristics have been staples of service research for more than two decades. Each of these characteristics poses certain challenges and requires specific strategies. These challenges revolve around understanding customer needs and expectations for service, tangibilizing the service offering, dealing with a myriad of people and delivery issues, and keeping promises made to customers (Zeithaml and Bitner, 1996). The distinctive characteristics of services pose difficulties in customer evaluation, lead to greater variability in operational inputs / outputs and emphasize the importance of time factor. As argued by Scheneider(2000), the underlying paradigm in services marketing since the 1980's has been that services are different from goods, a claim supported by an in-depth literature review (Fisk, Brown and Bitner, 1993), who concluded that "[four] featuresintangibility, inseparability, heterogeneity, and perishability- provided the underpinnings for the case that services marketing is field distinct from goods marketing." Shostack's (1977) work provided impetus to the argument that services marketing is unique. Gronroos, (1978); Gummesson, (1979) Berry (1980) and Lovelock (1981) contend that a different management approach is required for services marketing efforts.

Intangibility is not only the most widely cited difference between goods and services but also has been described as the critical distinction from which all other differences emerge (Bateson, 1979). Bateson drew a distinction between physical intangibility, that which is impalpable or cannot be touched and mental intangibility, that which cannot be grasped mentally. Intangibility of services poses the challenge of storing service and protecting new services through patents. Also because of intangibility, services cannot be readily displayed or easily communicated and pricing decisions also become difficult. Services are simultaneously produced and consumed(Inseparability) and the customer is present in the production process which makes mass production difficult. The quality of service and customer satisfaction depends on what happens in "real time" including action of employees and interactions between employees and customers (Bitner, 1996)". Since the customer must be present during the production of many services, inseparability "forces the buyer into intimate contact with the production process"(Carmen and Langeard, 1980; Norman and Ramirez, 1993). Inseparability also means that the producer and the seller are the same entity, making only direct distribution possible in most cases(Upah, 1980) and causing marketing and production to be highly interactive(Grönroos, 1978).

Heterogeneity reflects that no two services are precisely alike. The quality and essence of service can vary from customer to customer and from producer to producer and from day to day. Heterogeneity poses a challenge of maintaining consistent quality as behavior and performance vary not only among service workers but even between the same employee's interactions from one customer to another. Service performance from the same individual may also differ. Services are Perishable and therefore cannot be saved (Bessom \& Jackson, 1975; Thomas 1978). Service marketers claim that services cannot be stored for reuse at a later date, sold or returned (Edgett \& Parkinson 1993; Zeithaml, Bitner \& Gremler 2005; Lovelock \& Wirtz, 2006; Kotler \& 
Keller, 2006). Service organizations frequently find it difficult to synchronize supply and demand. Perishability leads to the challenge of inventorying the service and calls for strong recovery techniques for service failures.

These unique characteristic of service leads to specific problems for marketers of financial services and necessitate the use of special strategies for dealing with them (Zeithaml, Prasuraman, and Berry, 1985; Lovelock, Gummesson, 2004). Bonier \& Schneider (1985) argue that traditional managerial functions should be altered because of the unique characteristics of services. The understanding of how intangibility, heterogeneity, inseparability and perishability affected many services led a host of service researchers on several continents to recognize that knowledge about marketing in manufacturing was insufficient to understand services marketing(e.g. Grönroos, 1984; Gummesson, 1993; Rust, Moorman, and Dickson 2002; Zeithaml, Parasuraman, and Berry, 1990). New concepts are necessary if service marketing is to succeed (G Lynx Shostack, 1977). Verma (2003) in his study opines that service firms cannot survive if they rely on conventional reactive approach and marketing need to shift from customer satisfaction to customer delight.

However recently many authors (Enis and Roering 1981; Lovelock and Gummeson 2004; Vargo and Lusch 2004) have challenged the uniqueness of service particularly with advancements in technology and therefore the services-marketing-is-different debate has surfaced again. It is argued that these differences are based more or less on generalizations. It is also argued that these differences of degree have shrunk over time, for many kinds of services Further there is a growing view in literature that all firms compete on the basis of service(Grönroos 2000, 2007; Zeithaml and Bitner, 2000; Bitner, Brown and Meuter 2000). This has necessitated the need to revisit the concept of 'uniqueness of services'.

In spite of the fact that various studies have been conducted in the area of services marketing, there is a great need to further validate different models and recommendations due to significant changes in business environment. Most of the studies focus on comparing differences in buyer characteristics and only few compare how goods and services relate to their markets based on these differences. Even the literature, providing marketing implication arising out of the goods-services distinction and suggesting marketing strategies, suffers from certain drawbacks. The services marketing literature doesn't uncover the most critical problems facing most service firms today.

Most of the studies on services marketing (in light of the four unique characteristics of services) have been conducted across different service sectors. There is a need to study the topic in individual sectors to check the extent up to which these four characteristics are significant in specific sectors as the findings across sectors cannot present the exact picture of one particular sector. Moreover most of the research available in this field is carried in developed countries especially in USA and very less research work has been carried out in the Indian context.

Therefore the present article tests the validity of basic assertion of services marketing theory that four specific characteristics - intangibility, heterogeneity, inseparability, and perishability—make services uniquely different from goods and also analyses the data for difference in perception across sector.

\section{Literature Review}

Services marketing is built on carefully understanding the deeper needs of your customers, and then providing services that will help to make them more successful. The most consistently cited assumption in service marketing literature is that the major problems faced by services marketers arise from the basic characteristics like intangibility, inseparability, heterogeneity and perishability (e.g. Grönroos, 1978, 1990, 2000; Lovelock, 1981, 1983; Parasuraman et al., 1983, 1985; Zeithaml \& Bitner, 1996; Rust and Chung, 2005; Kasper et al. 2006) and the review is presented here under the same dimensions.

Rathmell (1974) while presenting a conceptual framework for the marketing challenges posed by the basic characteristics of services argues that intangibility of services creates the problem in display and communication of services. Langeard $(1975,1981)$ points out that intangibility of services lead to the problem in inventorying and protecting services through patents. Sessar (1976) suggest that because of intangibility services cannot be stored and therefore fluctuations in demand are often difficult to manage. Services cannot be patented legally and therefore new service concepts can easily be copied by competitors limiting the possibility of the firm to maintain its competitive advantage for long. Assael (1985) suggests that because of intangibility, positioning a service is more difficult than positioning a physical product because of the need to communicate vague and intangible benefits. Zeithaml (1988); Kraus (2000) argue that because of intangibility of services evaluating a service performance and making purchase decisions for services is difficult as compared with goods and therefore leads to greater emphasis on extrinsic cues rather than on intrinsic attributes. The intangibility of services also makes the evaluation of service quality more difficult, which means that consumers often depend on credence qualities to evaluate services (Zeithaml, 1981). Wolkins (1993) states that because of intangibility service quality is difficult to observe directly and customers may consider employee behavior as surrogate for service quality. Devlin (1997); Mathyssens (1998) point out that because of intangibility, the characteristics of services are complex and therefore communicating the value of a service offering to a customer is problematic. 
Bessom and Jackson (1975); Thomas (1978); Lovelock, (1996); (Kurtz \& Clow (1998), point out that because of perishability services cannot be saved. Further it is argued that since services are performances that cannot be stored, service businesses frequently find it difficult to synchronize supply and demand. Sometimes too much demand exists and sometimes too little demand exists. Sasser (1978) suggests that inseparability of services leads to the problem of difficulty in creating centralized mass production of services.

Grönroos (1978) in a research among several companies in Sweden and Finland, with regard to marketorientation of service as against physical goods, concludes that the main challenge in services is the difficulty of developing a concrete, tangible service offering. Further it is pointed out that because services are inseparable; other consumers are involved in production. Due to the simultaneous production and consumption, errors in service specification are noticed during the production and often by the customer, as opposed to errors noticed in a factory by manufacturing when they still can be corrected before delivery. Bateson and Hoffman (1997) mark that because of inseparability consumers are always involved in production and thus service quality cannot be controlled before it reaches the consumer. Berry $(1980,1987)$ argues that because services are produced and consumed simultaneously and often less standardized than goods, these unique characteristics of services present special challenges for services marketing. Carmen and Langeard, (1980), state that inseparability forces the buyer into intimate contact with the production process, since the customer must be present during the production of many services, which makes it difficult for the service provider to have full control over the outcome and the quality of the service delivered. Inseparability also means that the producer and the seller are the same entity, making only direct distribution possible in most cases Upah (1980). Chase \& Stewart, (1994), while extending the concept of Poka Yokes (suggested by Shigoe Shingo) i.e. fail safe method from manufacturing sector to service sector points out that, because of inseparability, customer error can directly affect the service outcome and therefore quality control becomes extremely difficult in services. Hartline and Ferrel (1996) while studying the impact of service employee management(empowerment, evaluation and commitment) in hotel industry suggest that because of inseparability quality control in services is very difficult as the attitude of customer-contact employees can influence customers' perceptions of the service.

According to Langeard et al. (1981), heterogeneity in service output is a particular problem for labour intensive services. Many different employees may be in contact with an individual customer, raising a problem of consistency of behavior. Knisely, (1979) puts forward the fact that service performance from the same individual may also differ. People's performance fluctuates with time and situation and level of consistency on which a consumer can count is not certain. Babakus, et al. (2003) in their study of frontline bank employees in Turkey point towards the fact that failures in service delivery are unavoidable as service are heterogeneous and performances and evaluation of service delivery process vary from person to person. This poses a big challenge to service providers as quality checks are almost impossible and the satisfaction of customers depends mostly on what happens in real time. Hess, R. et al. (2003), in a survey of 346 senior undergraduate business students at a large university find that service performance variability and failures arise from the inseparability of service production and consumption, which prevents quality inspection of most service prior to delivery. Ellram et al., (2007) suggests that it is difficult to provide consistent quality to service customers as services are provided by human beings and as such are related to the exchange of human knowledge, expertise and capabilities which can fluctuate from person to person and with time.

Heiskala et al, (2005) while attempting to synthesize the contradictory concepts of standardization and customization argue that the front-line vs. back-office dichotomy is a big challenge in services, and standardizing the service process may becomes difficult because of the involvement of customers whose actions may be more difficult to standardize than those of service workers as inherent heterogeneity implies variation from one encounter to another and from one customer to another.

Murray (1991), in an empirical study of 146 subjects, analyzed the information needs of service consumers and concludes that influencing the purchase decisions of service customers is challenging as service consumers have an increased information need and the buying decision of service consumers is greatly influenced by perceived risk and the ability of the consumer to acquire relevant information. According to Zeithaml \& Bitner (1996) customers have a more difficult time evaluating and choosing services than goods partly because services are intangible and non-standardized and partly because consumption is so closely interwined with production. These characteristics lead to differences in consumer evaluation process for goods and services in all stages of buying process. Also because experience and credence qualities dominate in services, consumers use different evaluation processes than those they use with goods. Further services cannot be readily displayed or easily communicated to customers, so the quality difference may be difficult for consumers to assess. Hence the decisions about what to include in advertising and other promotional materials are challenging. Axelsson and Wynstra (2002) claim that because of the characteristics of services (intangibility, heterogeneity, simultaneity and perishability), certain aspects of purchase process become more difficult than the purchase process for goods. Services are very complex, requiring the customer to follow a complicated and extensive series of actions to complete the process. This implies that the purchasing practices for goods cannot directly be applied to services thereby making it difficult for the services marketers to influence the purchasing 
decisions of the customers. Javalgi et al (2006) point out that since services are intangible and heterogeneous; most consumers will perceive higher risk while purchasing services than goods. Javalgi et al (2006) submit that Intangibility makes it more difficult to gather information about services. This makes information about services more expensive and may lead to consumers having less information about services than about goods. Further it is stated that since services are intangible and heterogeneous, most consumers will perceive higher risk in services than in goods.

\section{RESEARCH OBJECTIVES}

Following specific objectives have been set for the present study:

- To test the unique characteristics of service and the issues stemming from these characteristics in financial sector.

- To identify the most critical problems/challenges faced by marketers while marketing the services.

- To study the perceived difference of perception regarding the challenges of services marketing across sector (public and private).

\section{The Sample}

\section{Methodology}

Twenty financial service firms were selected including 12 banks and 8 insurance companies with an equal number of public and private sector companies in both the sectors. These organizations of financial services industry have been purposively selected to include both public and private sector in the sample and also to have a proper representation of firms operating at regional, national and international level. Further in Insurance sector both life and non life segments have been included. The questionnaire was distributed in selected cities of Delhi, Bangalore, Bombay, Chandigarh, Amritsar, Jammu and Srinagar. The selection of cities was made on the basis of convenience and the volume of business conducted. One hundred questionnaires were distributed in each of the twenty chosen companies making the total number of distributed questionnaires to 2000. In all 925 questionnaires were received making the response rate equal to $46.25 \%$. Out of which of 925 collected questionnaires 45 were found unfit for use therefore reducing the total number of usable questionnaires to 877 . To study the sample organizations precisely, proper care has been taken in selecting the sample so that it covers all the demographic features of the sample.

\section{Research Instrument:}

With a view to achieve objectives and test the hypothesis laid, primary data has been collected through a structured questionnaire administered to the managers of financial services sector. The questionnaire has been developed on the basis of review of literature and the discussion with the experts in the area of marketing of services. The questionnaire is devised on the basis of the design used by Zeithaml, Parasuraman and Berry (1985) for the study of problems and strategies in services marketing. The questionnaire contains three sections. The first section lists 15 items capturing the essence of what the literature suggests are difficulties unique to services. The first two items of this section seek to understand the extent of sensitivity of financial services marketers towards the uniqueness of services and the strategies required for the marketing of services. The rest of the section lists the statements of the problems faced by services marketers in the light of four unique characteristics of services and comprise of the following.

In both the sections the respondents were asked to indicate on a five point scale of 1 to 5 , the extent to which they agree or disagree with each statement. The 5-point Likert-scale technique assembles a number of opinion statements relevant to the issue. The scale assumes that each of the items measures the same underlying attitudes.

The second section includes items classifying respondents on the factors like age, qualification, level in management, gender and experience in service sector. Before finalizing the questionnaire a pilot survey of managers of financial services was made to seek their valuable views and suggestions, as ascertain the difficulties that can come across while administering the questionnaire. The questionnaire were revised after pre-testing stage and served as a base for the finalization of actual questionnaire for the present study.

\section{Pattern of Analysis:}

The data collected through primary and secondary sources has been analyzed statistically by applying various statistical tools such as Mean, Averages, Comparative Mean Averages, Standard Deviations, Correlation, and ANOVA. With the help of percentages, mean and standard deviation the relative impact of different factors has been analyzed. To see whether there is a significant difference between the perception of respondents across different dimensions various statistical techniques such as $\mathrm{Z}$ test and analysis of Variance(ANOVA) have been used. 
Services Marketing Theory Revisited: An Empirical Investigation into Financial Services Marketing Findings

The table 1, depicting the relative impact of services marketing problems for managers, show that the four distinguishing characteristics of services are still perceived to be highly challenging by services marketers as depicted by an mean score of more than 3 and in a few cases more than 4(except for the issue of service storage which has a mean of less than 3). Further it is seen that among all the listed issues, the performance of service employee being affected by his mood, difficulty in communicating the service offering to the customer and customers effecting each other's experience are seen as the three biggest challenges by the marketers of financial services. Employee's mood affecting his performance ranks $\mathrm{I}^{\mathrm{st}}$ with a mean score $(\mathrm{M})$ of 4.18 , suggesting that most of the managers feel that an unhappy service employee can create an unpleasant service experience. Services being difficult to communicate is seen to be the second prominent challenge by managers in the marketing of their services scoring a $\mathrm{M}$ of 3.99. It suggests that managers find it extremely difficult to explain the merits of their offerings to the customers. Customers effecting each other's experience ranks third with a $\mathrm{M}$ of 3.97 implying that the presence of customers during the service production process is seen as a big challenge by managers.

Items related to perishability are seen as least challenging by services marketers. Once a service is sold it cannot be returned as a defective physical product can be replaced by a new one. This is seen as a lesser challenge and has obtained rank 13 with a M of 3.39. The $14^{\text {th }}$ rank is obtained by DSSD with a M of 3.29. It reflects that supply and demand is difficult to match in services because of the unpredictable nature of men and machines. The last rank i.e. $15^{\text {th }}$ rank is obtained by SS having a M of 2.99 suggesting that services cannot be stored or further use.

Table 2 reveals in relative importance of services marketing challenges, dimension wise. It is observed that Heterogeneity (HET) is seen as the biggest challenge by the managers of financial sector scoring a $\mathrm{M}$ of 3.79 signifying that no two services are precisely alike. This is followed closely by Inseparability (INS) with a $\mathrm{M}$ of 3.78 suggesting that the presence of the customer in the production process is perceived as a big challenge by the managers of financial service firms. The customer's role as co-producer, customer-to-employee and customer-to-customer interactions are the major issues related to inseparability. Intangibility is next big challenge faced by financial services marketers with a $\mathrm{M}$ of 3.73. Intangibility of services poses the challenge of storing service and protecting new services through patents, display, communication, pricing and makes it more difficult for consumers to evaluate services than goods. However perishability as a services marketing challenge is seen to score lesser with a $\mathrm{M}$ of 3.22 .

Table 1:Relative Impact of Different Problems on Services Marketers

\begin{tabular}{|l|c|c|c|c|c|c|}
\hline Problems & Mean & $\begin{array}{c}\text { Standa } \\
\text { rd } \\
\text { Deviati } \\
\text { on }\end{array}$ & $\begin{array}{c}\text { Quart } \\
\text { ile } \\
(\mathrm{Q} 1)\end{array}$ & $\begin{array}{c}\text { Quart } \\
\text { ile } \\
\text { (Q3) }\end{array}$ & $\begin{array}{c}\text { Co-eff. Of } \\
\text { Variation( } \\
\text { CV) }\end{array}$ & $\begin{array}{c}\text { Ra } \\
\text { nk }\end{array}$ \\
\hline Services are difficult to display & 3.71 & 1.05 & 3.25 & 4.00 & 28.30 & $\mathbf{6}$ \\
\hline Services are difficult to communicate & 3.99 & 0.98 & 2.00 & 4.00 & 24.56 & $\mathbf{2}$ \\
\hline $\begin{array}{l}\text { Customers have limited understanding of } \\
\text { services }\end{array}$ & 3.61 & 1.09 & 3.00 & 4.00 & 30.2 & $\mathbf{8}$ \\
\hline It is difficult to set prices for services & 3.61 & 1.16 & 2.00 & 4.75 & 32.13 & $\mathbf{9}$ \\
\hline Quality of services is difficult to control & 3.96 & 1.05 & 3.00 & 4.00 & 26.52 & $\mathbf{4}$ \\
\hline $\begin{array}{l}\text { Difficult to match delivered service with } \\
\text { planned service }\end{array}$ & 3.45 & 1.18 & 2.00 & 4.00 & 34.20 & $\mathbf{1 2}$ \\
\hline $\begin{array}{l}\text { Service employee's mood affects his } \\
\text { performance }\end{array}$ & 4.18 & 1 & 3.50 & 4.50 & 23.92 & $\mathbf{1}$ \\
\hline It is difficult to standardize the services & 3.58 & 1.11 & 2.00 & 4.00 & 31.01 & $\mathbf{1 1}$ \\
\hline $\begin{array}{l}\text { Difficult to synchronize the supply to the } \\
\text { fluctuating demand }\end{array}$ & 3.29 & 1.09 & 2.00 & 4.00 & 33.13 & $\mathbf{1 4}$ \\
\hline services can not be returned & 3.39 & 1.18 & 2.00 & 4.00 & 34.81 & $\mathbf{1 3}$ \\
\hline Services cannot be Stored & 2.99 & 1.22 & 2.50 & 4.00 & 40.80 & $\mathbf{1 5}$ \\
\hline Presence of customer affects the outcome & 3.62 & 1.16 & 3.00 & 4.00 & 32.04 & $\mathbf{7}$ \\
\hline Customers effect each others experience & 3.97 & 0.87 & 3.00 & 4.00 & 21.91 & $\mathbf{3}$ \\
\hline Occurances of unprogrammable situation & 3.94 & 0.78 & 3.00 & 4.00 & 19.80 & $\mathbf{5}$ \\
\hline $\begin{array}{l}\text { Customer presence affects the efficiency } \\
\text { of service operation }\end{array}$ & 3.59 & 1.13 & 3.50 & 4.00 & 31.48 & $\mathbf{1 0}$ \\
\hline
\end{tabular}


Table 2:Overall Problems Faced by Services Marketers

\begin{tabular}{|l|c|c|c|c|c|}
\hline \multicolumn{1}{|c|}{ Problems } & Mean & $\begin{array}{c}\text { Standard } \\
\text { Deviation }\end{array}$ & $\begin{array}{c}\text { Quartile } \\
(\mathrm{Q} 1)\end{array}$ & $\begin{array}{c}\text { Quartile } \\
(\mathrm{Q} 3)\end{array}$ & Rank \\
\hline Intangibilty(INT) & 3.73 & 0.74 & 3.25 & 4.25 & 3 \\
\hline Heterogeneity(HET) & 3.79 & 0.71 & 3.25 & 4.50 & 1 \\
\hline Perishability(PER) & 3.22 & 0.82 & 2.67 & 4.00 & 4 \\
\hline Inseparability(INS) & 3.78 & 0.66 & 3.25 & 4.25 & 2 \\
\hline
\end{tabular}

\section{Sectorwise Analysis}

Table 3 shows the relative intensity of challenges across sectors. In case of difficulty in dispalying the service $(\mathrm{Z}=.03$ and $\mathrm{p}=.97)$, communicating the features of service $(\mathrm{Z}=1.7$ and $\mathrm{p}=.11)$, difficulty in matching the promised and delivered service $(Z=1.61$ and $p=0.1)$, impact of employee's mood on his performance $(Z=.25$ and $\mathrm{p}=.79)$, difficulty in matching supply and demand $(\mathrm{Z}=.93$ and $\mathrm{p}=.35)$, service once sold cannot be returned( $\mathrm{Z}=$ .85 and $\mathrm{p}=.39)$ and occurance of unprogrammable situations $(\mathrm{Z}=.01$ and $\mathrm{p}=.98)$ the public and private sector managers of are seen to be homogeneously challenged as the difference in mean is not found to be significant at 5 per cent significance level.

With respect to the problem of the limited understanding of customers ( $\mathrm{Z}=5.07$ and $\mathrm{p}<.0001)$, difficulty in pricing $(\mathrm{Z}=2.93$ and $\mathrm{p}=.003)$, difficulty in quality control $(\mathrm{Z}=2.31$ and $\mathrm{p}=.02)$, and difficulty in service standardization( $\mathrm{Z}=2.24$ and $\mathrm{p}=.02)$ a significant difference is reported between the mangers of public and private sector.Managers in public sector rate all these items higher reflecting that managers in public sector perceive these issues as more severe than the managers of private sector companies.

In cae of the issue of service storage $(Z=8.75$ and $p<.0001)$, presence of customers affceting the outcome of the service delivery process $(\mathrm{Z}=3.34$ and $\mathrm{p}=.001)$, customers effecting each others experience of the service received $\mathrm{Z}=2.37$ and $\mathrm{p}=0.018)$ and presence effecting the efficiency of the service proccess $(\mathrm{Z}=3.68$ and $\mathrm{p}=.0002$ ) managers in private sector perceive the issues to be more severe than those of public sector.

Table 4 shows all the dimensions of services marketing problems are showing a significant difference across sector at .05 level of significance except one dimension viz HET ( $\mathrm{Z}=.97$ and $\mathrm{p}=.33$ ) where managers are seen to be homogenously affected. In case if intangibility(INT) a significant difference is seen across public and private sector $(Z=3.52$ and $p=.0004)$ wherein intangibility is seen as more problematic issue by public sector managers as aginst the private sector managers. A highly significant diffrence is evident for perishability $(\mathrm{Z}=$ 4.20 and $\mathrm{p}<.001)$ and inseparability $(\mathrm{Z}=2.25$ and $\mathrm{p}=.02)$ a significant difference is reported between the mangers of public and private sector both posing a bigger challenge for private sector mnagers than those of public sector.

Table 3:Relative Intensity of Problems faced by Managers across Sectors

\begin{tabular}{|c|c|c|c|c|c|c|c|c|}
\hline Problems & Sector & $\mathbf{N}$ & Mean & S.D & Q1 & Q3 & $\mathbf{Z}$ & Sig \\
\hline \multirow{2}{*}{$\begin{array}{l}\text { Services are } \\
\text { difficult to } \\
\text { display }\end{array}$} & Public & 387 & 3.70 & 1.00 & 3.00 & 4.00 & \multirow{2}{*}{0.03} & \multirow{2}{*}{0.97} \\
\hline & Private & 490 & 3.71 & 1.09 & 3.00 & 4.00 & & \\
\hline \multirow{2}{*}{$\begin{array}{l}\text { Services are } \\
\text { difficult to } \\
\text { communicate }\end{array}$} & Public & 387 & 4.04 & 0.86 & 3.50 & 4.50 & \multirow[b]{2}{*}{1.57} & \multirow[b]{2}{*}{0.11} \\
\hline & Private & 490 & 3.94 & 1.07 & 3.25 & 4.50 & & \\
\hline \multirow{2}{*}{$\begin{array}{l}\text { Customers have } \\
\text { limited } \\
\text { understanding of } \\
\text { services }\end{array}$} & Public & 387 & 3.82 & 0.92 & 4.00 & 4.00 & \multirow[b]{2}{*}{5.07} & \multirow[b]{2}{*}{0.00} \\
\hline & Private & 490 & 3.45 & 1.18 & 2.00 & 4.00 & & \\
\hline \multirow{2}{*}{$\begin{array}{l}\text { It is difficult to } \\
\text { set prices for } \\
\text { services }\end{array}$} & Public & 387 & 3.74 & 1.14 & 3.00 & 5.00 & \multirow{2}{*}{2.93} & \multirow{2}{*}{0.003} \\
\hline & Private & 490 & 3.51 & 1.16 & 2.00 & 4.00 & & \\
\hline \multirow{2}{*}{$\begin{array}{l}\text { Quality of } \\
\text { services is } \\
\text { difficult to } \\
\text { control }\end{array}$} & Public & 387 & 4.05 & 0.93 & 3.75 & 4.50 & \multirow[b]{2}{*}{2.31} & \multirow[b]{2}{*}{0.02} \\
\hline & Private & 490 & 3.89 & 1.13 & 4.00 & 5.00 & & \\
\hline
\end{tabular}


Services Marketing Theory Revisited: An Empirical Investigation into Financial Services Marketing

\begin{tabular}{|c|c|c|c|c|c|c|c|c|}
\hline \multirow{2}{*}{$\begin{array}{l}\text { Difficult to } \\
\text { match delivered } \\
\text { service with } \\
\text { planned service }\end{array}$} & Public & 387 & 3.38 & 1.17 & 2.00 & 4.00 & \multirow[b]{2}{*}{1.61} & \multirow[b]{2}{*}{0.10} \\
\hline & Private & 490 & 3.51 & 1.18 & 2.00 & 4.00 & & \\
\hline \multirow{2}{*}{$\begin{array}{l}\text { Service } \\
\text { employee's } \\
\text { mood affects his } \\
\text { performance }\end{array}$} & Public & 387 & 4.17 & 1.08 & 4.00 & 5.00 & \multirow[b]{2}{*}{0.25} & \multirow[b]{2}{*}{0.79} \\
\hline & Private & 490 & 4.18 & 0.93 & 4.00 & 5.00 & & \\
\hline \multirow{2}{*}{$\begin{array}{l}\text { It is difficult to } \\
\text { standardize the } \\
\text { services }\end{array}$} & Public & 387 & 3.68 & 0.98 & 3.00 & 4.00 & \multirow{2}{*}{2.24} & \multirow{2}{*}{0.02} \\
\hline & Private & 490 & 3.51 & 1.20 & 2.00 & 4.00 & & \\
\hline \multirow{2}{*}{$\begin{array}{l}\text { Difficult to } \\
\text { synchronize the } \\
\text { supply to the } \\
\text { fluctuating } \\
\text { demand }\end{array}$} & Public & 387 & 3.25 & 1.08 & 2.00 & 4.00 & \multirow[b]{2}{*}{0.93} & \multirow[b]{2}{*}{0.35} \\
\hline & Private & 490 & 3.32 & 1.10 & 2.00 & 4.00 & & \\
\hline \multirow{2}{*}{$\begin{array}{l}\text { services can not } \\
\text { be returned }\end{array}$} & Public & 387 & 3.43 & 1.19 & 2.00 & 4.00 & \multirow{2}{*}{0.85} & \multirow{2}{*}{0.39} \\
\hline & Private & 490 & 3.36 & 1.17 & 2.00 & 4.00 & & \\
\hline \multirow{2}{*}{$\begin{array}{l}\text { Services cannot } \\
\text { be Stored }\end{array}$} & Public & 387 & 2.60 & 1.14 & 2.00 & 3.00 & \multirow{2}{*}{8.75} & \multirow{2}{*}{$0.00^{*}$} \\
\hline & Private & 490 & 3.30 & 1.20 & 2.00 & 4.00 & & \\
\hline \multirow{2}{*}{$\begin{array}{l}\text { Presence of } \\
\text { customer affects } \\
\text { the outcome }\end{array}$} & Public & 387 & 3.48 & 1.25 & 2.00 & 4.00 & \multirow[b]{2}{*}{3.34} & \multirow[b]{2}{*}{0.001} \\
\hline & Private & 490 & 3.74 & 1.08 & 4.00 & 4.00 & & \\
\hline \multirow{2}{*}{$\begin{array}{l}\text { Customers effect } \\
\text { each others } \\
\text { experience }\end{array}$} & Public & 387 & 4.05 & 0.87 & 4.00 & 5.00 & \multirow[b]{2}{*}{2.37} & \multirow[b]{2}{*}{0.01} \\
\hline & Private & 490 & 3.91 & 0.86 & 4.00 & 4.00 & & \\
\hline \multirow{2}{*}{$\begin{array}{l}\text { Occurances of } \\
\text { unprogrammable } \\
\text { situation }\end{array}$} & Public & 387 & 3.94 & 0.79 & 4.00 & 4.00 & \multirow{2}{*}{0.01} & \multirow{2}{*}{0.98} \\
\hline & Private & 490 & 3.94 & 0.78 & 4.00 & 4.00 & & \\
\hline \multirow{2}{*}{$\begin{array}{l}\text { Customer } \\
\text { presence affects } \\
\text { the efficiency of } \\
\text { service } \\
\text { operation }\end{array}$} & Public & 387 & 3.44 & 1.16 & 2.00 & 4.00 & \multirow[b]{2}{*}{3.68} & \multirow[b]{2}{*}{.0002} \\
\hline & Private & 490 & 3.72 & 1.10 & 3.00 & 4.00 & & \\
\hline
\end{tabular}

Note:- '*' means the significance level is <.0001.

Table 4:Relative Intensity of Overall Problems Faced by Services Marketers across Sectors

\begin{tabular}{|c|c|c|c|c|c|c|c|c|}
\hline Problems & Sector & $\mathbf{N}$ & Mean & S.D & Q1 & Q3 & $\mathbf{Z}$ & Sig \\
\hline \multirow{2}{*}{ Intangibilty(INT) } & Public & 387 & 3.83 & 0.66 & 3.50 & 4.25 & \multirow{2}{*}{3.52} & \multirow{2}{*}{0.0004} \\
\hline & Private & 490 & 3.65 & 0.79 & 3.25 & 4.25 & & \\
\hline \multirow{2}{*}{ Heterogeneity(HET) } & Public & 387 & 3.82 & 0.69 & 3.50 & 4.50 & \multirow{2}{*}{0.97} & \multirow{2}{*}{0.33} \\
\hline & Private & 490 & 3.77 & 0.73 & 3.25 & 4.50 & & \\
\hline \multirow{2}{*}{ Perishability(PER) } & Public & 387 & 3.09 & 0.86 & 2.67 & 3.67 & \multirow{2}{*}{4.20} & \multirow{2}{*}{$0.00 *$} \\
\hline & Private & 490 & 3.33 & 0.78 & 2.67 & 4.00 & & \\
\hline \multirow{2}{*}{ Inseparability(INS) } & Public & 387 & 3.73 & 0.72 & 3.00 & 4.25 & \multirow{2}{*}{2.25} & \multirow{2}{*}{0.02} \\
\hline & Private & 490 & 3.83 & 0.61 & 3.50 & 4.25 & & \\
\hline
\end{tabular}

Note:- '*' means the significance level is $<.0001$.

\section{Discussion}

Managers in financial sector are seen to be facing enormous challenges while marketing their offerings and the impact of four differentiating characteristics of services(IHIP) on the marketing of financial services is found to be fairly high. The intensity of issues faced by managers is fairly high as depicted by high mean scores. It is seen that managers in both banking and insurance industry are subjected to immense challenges in selling the services as financial services are highly intangible and complex in nature. The managers of the financial services sector find themselves most often fighting the challenge of heterogeneity of services as this issue 
reports the highest mean score out of the four issues(IHIP). It is found that managers find it almost impossible to ensure that all the customers receive a standardized service experience as it is affected by a myriad of factors like the behavior, mood and attitude of the frontline employees, the timing of a working day, as well as the participation level of the customer which are most often very difficult to control.

Among the different dimensions of heterogeneity, the biggest challenge for marketers in financial services sector is that the behavior of customer contact employees profoundly affects the satisfaction level of the customers. The managers find it difficult to ensure consistency of behavior of frontline employees as the behavior is shaped by myriad of factors most of which are beyond the control of the managers.

The inseparability of the customer from the service production process is viewed as one of the biggest challenges by most of the managers in financial sector. It is believed that the presence of customer in the production process not only affects the efficiency of the process but also leaves the service provider with a minimal amount control on the output and the quality of the service delivered.

The managers of financial services firms report intangibility as a major challenge in selling the services to customer, however contrary to earlier findings in service sector, intangibility is seen as a lesser challenge than heterogeneity and inseparability. As a result of intangibility services are difficult to display and communicate to the customers. Intangibility also makes service pricing a highly challenging job.

The managers relatively are seen to have less trouble tackling perishability of services as this dimension scores the lowest out of the four basic dimensions(IHIP). The recent technological advancements of internet, telecommunication and information technology have made managers better equipped to overcome the challenges of service storage and demand supply mismatch.

The least significant problem for managers is found to be the inability to store the services which is an implication of perishability. In financial sector this is not seen as a big hurdle by managers arguably aided by the benefits of Internet, ATMs, IT and other technological advancements. Another interesting finding is that, while intangibility emerged as the most critical challenge for service marketers in earlier works on services marketing field, it is seen that for financial services marketers, heterogeneity is the most burning issue.

\section{Suggestions and Policy Implications for Dealing With Marketing Challenges in Financial Sector}

In the light of the conclusions drawn from the analysis of the data following are suggestions to help the managers of financial sector to overcome the challenges faced by them while marketing their offerings

- There is a need to analyze the marketing challenges across different types of services in order to identify the issues unique to them, as the intensity of challenges varies in different services.

- As the degree of impact of different challenges varies, service marketers need to identify the most critical ones specific to their industries and work on them on priority basis.

- As it is seen that technological advancements have rendered issues of intangibility and perishability less challenging in financial services, there is a need to make use of technology to overcome the more challenging issues of heterogeneity and perishability.

- Further research is required to understand the reasons for the difference in the perception of marketers in public and private sector regarding the impact of services marketing challenges.

- The biggest challenge faced by financial service marketers is heterogeneity and to overcome this the marketers can use a host of strategies like (a) keep the service stations (branches) well equipped with modern infrastructure to give a message of high quality service standards to the customers (b) reward the strong performers with financial and nonfinancial incentives to increase job satisfaction and ultimately ensure positive attitudes from the customer contact employees(c) train their frontline employees in skills like reliability, responsiveness, assurance and empathy to help them deliver good quality service to the customers(d)s employees should be empowered to decide about the best way to serve customers as too many rules tend to inhibit the judgment of employees to cater to the heterogeneous nature of service customers' needs and the lower management needs to be sensitized about it.(e)be constantly prepared to respond to a service failure in a way that will preserve their credibility. Strong recovery techniques should be used to convert an unpleasant experience of customer during a failed service into an opportunity to lead to a more satisfied service encounter.

\section{Limitations Of The Study}

The cooperation and interest of respondents posed a serious problem in few cases as research was based on exclusive survey. Some respondents showed little interest in filling the questionnaire and even sometimes doubted the credibility of researcher. Also some respondents particularly in lower management had difficulty in understanding few questions and had to be assisted to fill respond to those questions which may have led to some influence on the perception of those respondents. Since the survey was conducted at national level, all the respondents could not be reached personally and their responses were collected through mail. The inherent problems associated with mailing questionnaires also become one of the limitations of this research. 
Another important limitation with the research is that the cities from which data is collected have been selected as per the convenience and therefore some of the major cities were not included in the sample space due to time and resource constraints.

As only one service industry was included in the sample, extrapolating the findings from this research to other service industries should be done with care given that consumption motives and perceived time pressures may vary greatly across different service industries.

Despite these limitations, efforts were made that these limitations do not come in the way of arriving at an authentic conclusion. The sample selection was done very carefully to make the sample representative of the whole population. Further the respondents were guided thoroughly to understand the questions wherever they faced any difficulty. To reduce the limitations of responding through mail, telephone calls were made to the respondents who responded through male.

\section{References}

[1] Assael, Henrey (1985), "Marketing Management: Strategy and Action. Boston: Kent.Anderson, E.W., Fornell, C. And Ronald T. Rust (1997), "Customer Satisfaction, Productivity, and Profitability: Differences Between Goods and Services", Marketing Science, Vol. 16(2), pp 129-142.

[2] Axelsson, B. and Wynstra, F. (2002), Buying Business Services, Wiley, Chichester.

[3] Babakus, E., Yavas, U., Karatepe, O.M \& Avci T. (2003),'The Effect of Management Commitment to Service Quality on Employees' Affective and Performance Outcomes” Journal of Academy of Marketing Science, Vol 31(3), pp $272-286$.

[4] Bateson, J.E.G and Hoffman, K.D., (1997) Essentials of Services Marketing, Orlando, The Dryden Press

[5] Bateson, J.E.G, (1979), "Why We Need Services Marketing,” in O.C. Ferrel, S.W. Brown, and C.W Lamb, Jr.(Eds), Conceptual and Theoretical Developments in Marketing, Chicago, American Marketing, 131-146

[6] Berry, Leonard L., (1980) "Services Marketing is Different," Business, Vol. 30(May-June), pp. 24-29.

[7] Bessom, Richard M. and Jackson, David W. (1975), "Service Retailing-A Strategic Marketing Approach," Journal of Retailing, 8(Summer), pp. 137-149.

[8] Bitner, M . J ., Brown , S . W . \& Meuter, M . L . (2000), "Technology Infusion in Service Encounters, Journal of the Academy of Marketing Science, Vol. 28(1), pp. $138-149$

[9] Carmen, James M. and Langeard, Eric (1980), "Growth Strategies of Service Firms," Strategic Management Journal, 1(JanuaryMarch), pp. 7-22

[10] Chase, R. B. and Stewart, D. M.(1994) "Make Your Service Fale Safe” Sloan Management Review, Vol. 35(3), pp.35-44.

[11] Devlin, J.F. (1997), “Adding value to retail financial services. J. of Marketing Practice: Applied Marketing Science, ” Vol. 3(4), pp. 251-267

[12] Edgett, Scott \& Parkinson Stephen (1993), "Marketing for Service Industries- a Review," The Service Industries Journal, Vol. 13(July), 19-39.

[13] Ellram, L.M., Tate, W.L. \& Billington, C. (2007), "Services Supply Management: The Next Frontier for Improved Organizational Performance", California Management Review, Vol. 49(4), pp. 44-66.

[14] Enis, Ben M. and Roering, Kenneth J. (1981), "Service Marketing: Different Products, Similar Strategy," in Marketing of Services, J.H. Donnelley and W. R. George eds., Chicago: American Marketing, pp. 1-4.

[15] Fisk, R.P, Brown, S.W. Bitner, M.J. (1993), “Tracking the Evolution of Services Marketing Literature,” Journal of Retailing, (Spring), 61-103.

[16] Grönroos, C. (1978), “A Service Oriented Approach to Marketing of Services”, European Journal of Marketing, Vol. 12(8), pp 588-601.

[17] Grönroos, C. (1984), “A Service Quality Model and Its Implications,” European Journal of Marketing, Vol. 18, No. 4 pp 36-44

[18] Gronroos, C. (1990) "Service Management and Marketing”, Massachusetts Lexington Books, pp. 27.

[19] Grönroos, C. (2000), Service Management and Marketing: A Customer Relationship Management Approach. Second Edition. ISBN 0-471-72034-8. John Wiley \& Sons, Ltd.

[20] Grönroos, C.(2007), “Service Management and Marketing: Managing in Service Competition, Chichester: $3^{\text {rd }}$ edition, John Wiley and Sons, London.

[21] Gummesson, E. (1979), "The Marketing of Professional Services - an Organizational Dilemma," European Journal of Marketing , Vol. 13(5), pp. 308-318.

[22] Gummesson, E. (1993), "Quality Management in Service Organizations: An Interpretation of the Service Quality Phenomenon and a Synthesis of International Research,” Research Report, ISQA Service Quality Association .

[23] Hartline M.D. \& Ferrel, O.C. (1996) "The Management of Customer Contact Service Employees: An Empirical Investigation" Journal of Marketing, Vol. 60, pp. 52-70.

[24] Heiskala, M., Paloheimo, K.-S. \& Tiihonen, J. (2005), "Mass Customisation of Services: Benefits and Challenges of Configurable Services. Frontiers of e-Business Research,(February)2005. Conference Proceedings of eBRF, 26.-28.9.2005, Tampere, Finland.

[25] Hess Jr, L., Hess Jr, R., Ganesan S. \& Klein, N.M., (2003) "Service failure and Recovery: The Impact of Relationship Factors on Customer Satisfaction," Journal of Academy of Marketing Science, 31(2), pp. 127-145.

[26] Javalgi, R.G., Martin, C. L., \& Young, R. B. (2006), "Marketing Research, Market Orientation and Customer Relationship Management: A framework and Implications for Service Providers" Journal of Services Marketing, Vol. 20(1), pp. 12-23

[27] Kasper H Van Helsdugen, P and Gabbot M (2006) Services Marketing Management : A Strategic Perspective Chichester John Wiley $2^{\text {nd }}$ Edition.

[28] Keith B Murray, (1991) “A Test of Services Marketing Theory: Consumer Information Acquisition Activities”, Journal of Marketing, Vol. 55(January), pp. 10-25.

[29] Knisely, Gary(1979), “Financial Services Marketing Must Learn Packaged Goods Selling Tools,” Advertising Age, Vol. 50(March 19), pp. 58-62.

[30] Kotler P. \& Keller, K.L (2006) Marketing Management $12^{\text {th }}$ edition, New Jersey : Pearson Prentice Hall Cooper, D.R \& Schindler P.S - Business Research Methods - Boston MC Graw Hill Irwin.

[31] Kraus, paul J.(2000), "Pricing the Service Offering," in Handbook of Services Marketing and Management, Teresa A.. Swartz and Dawn Lacobucci, eds. Thousand Oaks, C.A: Sage Publications. Pp. 191-202.

[32] Kurtz, D. L. and Clow, K. E. (1998), Services Marketing, John Wiley \& Sons, New York. 
[33] Langeard, Eric, Bateson, J. E.G. Lovelock, C. H. and Eigler, P. (1981), Service Marketing: New Insights from Consumer and Managers, Cambridge, MA: Marketing Science Institute.

[34] Lauren K. Wright - Journal of Marketing Education "2005” Beyond Good and Services - An Elaborate product classification on pragmatic grounds.

[35] Lovelock C (2001) Services Marketing: People Technology Strategy, $4^{\text {th }}$ edition Upper Saddle River, Prentice Hall

[36] Lovelock, C, and Gummesson, E. (2004), "Whither Services Marketing? In Search of a New Paradigm and Fresh Perspective," Journal of Service Research, 7 (1), 20-41.

[37] Lovelock, C. H. (1981), "Why Marketing Management Needs To Be Different for Services," in Marketing of Services, J.H. Donnelley and W.R. George, eds., Chicago: American Marketing, pp. 5-9.

[38] Lovelock, C., Wirtz, J. 2006. Service Marketing: People, Technology, Strategy, 6th Edition, Prentice Hall Upper Saddle, NJ.

[39] Lovelock.,C.H., (1983), "Classifying Services to Gain Strategic Marketing Insights," Journal of Marketing, Vol.47(Summer).

[40] Normann, R. \& Ramirez, R. (1993), "From Value Chain to Value Constellation," Harvard Business Review, Jul/Aug, pp. 65-77.

[41] Parasuraman, A., Berry, L.L. and Zeithaml, V.A. (1983), "Service Firms Need Marketing Skills," Business Horizons, Vol. 26(6), pp. 28-31.

[42] Rathmell, J. M. (1974), "Marketing in the Services Sector, Cambridge, MA: Winthrop.

[43] Rust, R. T., Moorman, C. and Dickson, P. R.(2002), "Getting Return on Quality: Revenue Expansion, Cost Reduction, or Both?," Journal of Marketing Vol.66 (October), pp. 7-24.

[44] Rust T Roland Chung Slong Tuck - Marketing Sciences, Marketing Models of Services and Relationships - Vol. 25 , No. 6 NovDec 2006, PP 560-580.

[45] Sasser, W, Earl, Jr. (1976), "Match Supply and Demand in Service Industries," Harvard Business Review, Vol. 54(NovemberDecember), pp. 133-140.

[46] Sasser, W., Earl, Jr., and Arbeit ,S. (1978), "Selling Jobs in the Service Sector," Business Horizons, Vol. 19(June), pp. 61-65

[47] Shostack G.L, (1997) "Breaking Free From Product Marketing," Journal of Marketing, Vol. 41(2), pp.73-80.

[48] Shostack, G. L.(1977) 'Human Evidence: A New Part of Marketing Mix' Bank Marketing, March pp 32-34

[49] Singhvi, S.R. (1995) "Marketing of Services," Political Economy Journal of India Vol 5(2),

[50] Thomas, Dan R. E. (1978). "Strategy is Different in Service Business," Harvard Business Review, 56(July-August), pp. 158-165

[51] Upah, Gregory D. (1980), "Mass Marketing in Service Retailing, A Review and Synthesis of major Methods," Journal of Retailing, 56(Fall), pp. 59-76.

[52] Vargo, S.L. \& Lusch, R.F. 2004, "The Four Service Marketing Myths: Remnants of a Goods-Based Manufacturing Model," Journal of Service Research, Vol. 6(4), pp.324-335

[53] Verma, Harsh V. 2003 "Customer Outrage and Delight" Journal of Services Research, Vol3(1), pp. 119-133.

[54] Wolkins D. Otis(1993), "Service Quality Principles," in The Service Quality Handbook, Eberhard E. Sceuing and William F. Christopher, eds New York: American Management Association Press

[55] Zeithaml, V. A. and Bitner, M. J. (2000), Services Marketing: Integrating customer focus across the firm, 2nd ed., McGraw-Hill, London.

[56] Zeithaml, V. A.(1988), "Consumer Perceptions of Price, Quality and Value: A Means End Model and Synthesis of Evidence," Journal of Marketing, Vol. 52 (July), pp. 2-22.

[57] Zeithaml, V., Bitner, M.J., and Gremler, D.,(2005) "Services Marketing:Integrating Customer Focus Across the Firm, $4^{\text {th }}$ ed.( McGraw-Hill, London)

[58] Zeithaml, V.A. (1981), "How consumer evaluation processes differ between goods and services", in Donnelly, J. and George, W. (Eds), Marketing of Services, American Marketing Association, Chicago, IL.

[59] Zeithaml, V.A., and Bitner M.J. (1996), Services Marketing, Singapore, McGraw-Hill.

[60] Zeithaml, V.A., Parasuraman, A., Berry, L. (1985), "Problems and Strategies in Services Marketing. Journal of Marketing. Vol. 49. Pp. 33-46.

[61] Zeithaml, V.A., Parasuraman, A., Berry, L.(1990), "Delivering Quality Service: Balancing Customer Perceptions and Expectations(New York:Free Press) 